\title{
Early Successions in the Floodplain of the Kamp River (Austria)
}

\author{
Johannes Tintner ${ }^{1, *}$ and Brigitte Klug ${ }^{2}$ \\ ${ }^{1}$ Institute of Wood Science and Technology, ${ }^{2}$ Institute of Botany, University of Applied Life Sciences and Natural \\ Resources, Vienna, Austria
}

\begin{abstract}
In 2002, large riparian parts of the river Kamp in Lower Austria were affected by a flood which eradicated almost all vegetation at the riverside. From 2003 to 2012 the authors documented early stages of succession at five specific sites with characteristic vertical and horizontal distances to the river. Phytosociological relevés were performed. Ecological indicator values, life traits, diversity indices (species number, evenness) and Sørensen index were used to describe the development within this period. The results demonstrate that, after five years, succession had usually reached a stage where highly competitive species like Phalaris arundinacea or Alnus glutinosa dominate. The first year after the flood annuals, lots of them common ruderals, dominated. The second year a change to biennial species took place. This transition was paralleled by a numeral maximum of species in the second year. Differences were only evident at a site where vegetation had not been completely eradicated by the flood. At this site a rudimentary stage of annuals was directly followed by an increase of Phalaris arundinacea that had been formerly present as well. Succession dynamics were stronger where conditions did not favor competitive species, which led to higher evenness values. Evenness values decreased, whenever Phalaris or Alnus achieved the dominance. As a matter of fact, these vegetation types showed a minimum in biodiversity. Maxima of evenness were found in vegetation with a high percentage of ruderals and shortliving species.
\end{abstract}

Keywords: Early successional stages, biodiversity, evenness, ecological indicator values.

\section{INTRODUCTION}

Vegetation development is steered by site conditions on the one hand and diaspore supply on the other hand. A typical succession after a disastrous flood would commence with a pioneer phase of short-lived, annual species. Usually these species are succeeded by biennials dominating for some years. The later phases are characterized either by perennial grasses and forbs, which can be very invasive, or by shrubs and fast growing pioneer trees. The latest successional stages comprise slowly growing tree species, which are usually rather competitive and shade tolerant (Grime 2001). Along rivers the typical pattern is periodically or episodically disturbed by floods and the resulting changes of the river bed structure and material. Typical floodplain plant species are fostered by their tolerance against low oxygen supply in the root zones and fast regeneration after mechanical stress.

In August 2002 large parts of the Kamp valley in Lower Austria were affected by an extraordinary flood. Although such events are disastrous for people living and working in the region, for ecologists they usually provide a natural possibility to study ecosystem dynamics in a large-scale experiment.

This work took the chance to document the succession at sites with different preconditions in the Kamp valley. Based

*Address correspondence to this author at the Institute of Wood Science and Technology, Vienna, Austria; Tel: +43-1-47654-4245;

Fax: +43-1-47654-5154; E-mail: johannes.tintner@boku.ac.at on phytosociological relevés both the distribution of plant species and their interactions (dominance, facilitation, and competition) were assessed. Various concepts are available and commonly in use to describe vegetation changes (Bråkenhielm and Liu 1998, Ellenberg 1996, Grime 2001, Tilman 1988). However, it is still difficult to find significant parameters to describe favorable plant succession (Critchley 2000). Undisturbed successions most often lead to rather species poor communities, although it has become a common goal to keep biodiversity as high as possible. Therefore six different sites along the river were chosen, where site specific developments of the plant layers were expected. Thus we hoped to find out whether biodiversity issues can be applied under these preconditions.

\section{SITES AND METHODS}

\section{Site Description}

In order to document different possible successions, five specific sites were selected that represented different preconditions for vegetation succession (Muhar et al. 2004). Table 1 gives an overview over the situation at the sites.

The valley width near site A is smaller than $250 \mathrm{~m}$. The potential natural vegetation near the river would be dominated by black alder (Alnus glutinosa) or by silver willow (Salix alba). The mean water runoff of the river at this place was between 5 and $25 \mathrm{~m}^{3} / \mathrm{s}$ at a gradient of about 3 $\%$. The site was situated near a dam of a power station at an elevation of about 250 mas. 1. The relevé area was surrounded by black alder trees. 
Table 1. General data at the Study Sites

\begin{tabular}{|c|c|c|c|c|c|}
\hline & Site A & Site B & Site C & Site D & Site $\mathbf{E}$ \\
\hline $\operatorname{Area}\left(\mathbf{m}^{2}\right)$ & 40 & 40 & 35 & 40 & 30 \\
\hline Vertical distance to water level (m) & 1.0 & 0.8 & 0 & 0 & 0.5 \\
\hline Horizontal distance to the main river $(\mathrm{m})$ & 30 & 80 & 0 & 0 & 50 \\
\hline Direct influence of the flood 2002 & high & high & high & medium & high \\
\hline Direct influence of the small flood 2006 & none & none & low & low & low \\
\hline
\end{tabular}

Sites B, C and D were located some hundred meters downstream. Site B was situated on a sand bank of about $50 \mathrm{~cm}$ in height, which had been created by the flood in 2002. Site C was situated directly at the river bank. Therefore the site was flooded twice in subsequent years, but without complete destruction of the vegetation. Site D is protected against floods by a stone hillock. The last site $\mathrm{E}$ is situated about $11 \mathrm{~km}$ downstream near a new arm of the river created by the flood. In 2003 this new arm contained no water; thus an assessment of the vegetation was possible. In the following years the arm was always filled with water, therefore scarce vegetation was observed. Only in 2007 the arm was dry and vegetated again.

\section{Methods}

In September 2003 all sites were monitored for the first time and phytosociological relevés were performed. Ecological indicator values for the vegetation as described by Ellenberg (Karrer and Kilian 1990, Ellenberg et al. 1992) were used, and the life traits and life spans of the species were assessed to display the change of vegetation over a period of ten years. The development of the indices for species diversity and evenness were also calculated in order to understand the changes in site conditions. The nomenclature of the species according to Fischer et al. (2008) was applied. The cover of every species was estimated using a combination of the Braun-Blanquet (1964) and Londo (1976) scales as described in Smidt et al. (2007) or Tintner and Klug (2006). Weighted ecological indicator values for moisture, soil reaction and nutrient supply (Ellenberg et al. 1992) were calculated for every relevé.

$$
F_{\text {mean }}=\frac{\sum\left(w_{i} \times F_{i}\right)}{\sum w_{i}}
$$

where $\mathrm{F}$ means moisture value and w means weight.

As the Kamp valley is situated at the western border of the Pannonian climate region, the indicator values from Karrer and Kilian (1990), adapted to Eastern Austrian conditions, were used instead of Ellenberg's values. For each species of a relevé, the respective indicator was weighted by the species coverage, and by this a weighted average value for the entire relevé was calculated. This calculation was supported by the software VegePro (C Irene Ahamer).

The herbal layer species were grouped according to their life spans into annuals, biennials, perennial grasses and forbs and perennial woody species (shrubs and trees). For many species this classification is difficult, as they can reproduce annually but can survive even for several years. Following the demands for further mathematical procedures, these species were assigned to only one trait. The resulting error was minimized by the big amount of data points in one relevé.

Furthermore the total number of species and the total cover at every relevé were evaluated which allows the calculation of the relative and absolute portion of cover represented by the specific life traits. The indicator values and the life traits were calculated for both the total vegetation and the herbal layer. Species numbers were taken from the herbal layers of the relevés.

As parameter of diversity we used H' - calculated by the Shannon-Wiener function - (Tremp 2005).

Evenness was calculated as follows:

$\mathrm{E}=\mathrm{H}^{\prime} / \mathrm{H}_{\max }$; where $\mathrm{H}_{\max }=\ln \mathrm{s} ; \mathrm{s}=$ total number of species.

To compare ß-diversity between years and sites, the coefficient of Sørensen (1948) was used. This method compares two vegetation lists. The index is calculated as follows:

Index $=2 * a /(2 * a+b+c)$; where $a=$ number of species in both lists, $b$ and $c$ are the number of species in just one of the two lists

Principal Component Analysis (PCA) was carried out using Unscrambler 9.2 (Camo). PCA matrices were created where the coverage of all species with a certain indicator value was summed up. Therefore the matrix consisted of the $\mathrm{R}$ - and the $\mathrm{N}$-value with nine columns (one column for each step of the indicator scale) and the F-value with 12 columns respectively. The ubiquitous species reflecting moderate or average conditions (defined by humidity indicator $\mathrm{F}$, soil reaction indicator $\mathrm{R}$ or nutrient indicator $\mathrm{N}$ between 5 and 7) were removed from the data matrix, as they do not reflect extreme site conditions. The resulting parameter set for the PCA comprised the F-values " 1 " to " 4 " and " 8 " to " 12 ", the R-values "1" to " 4 " and " 8 " to "9", the N-values " 1 " to "4" and " 8 " to " 9 ". Life traits were indicated in ranges from " 1 " to "4" as reported by Tintner and Klug (2011).

\section{RESULTS AND DISCUSSION}

\section{Species Dynamics}

Site A had been completely deprived of vegetation by the flood of 2002. In the first year after the flood a typical annual stage was established. Mainly species of the Chenopodietea dominated. In the second year vegetation diversified (Fig. (1). Perennial grasses (especially Phalaris arundinacea and Agrostis stolonifera) grew up, annual 
(a)

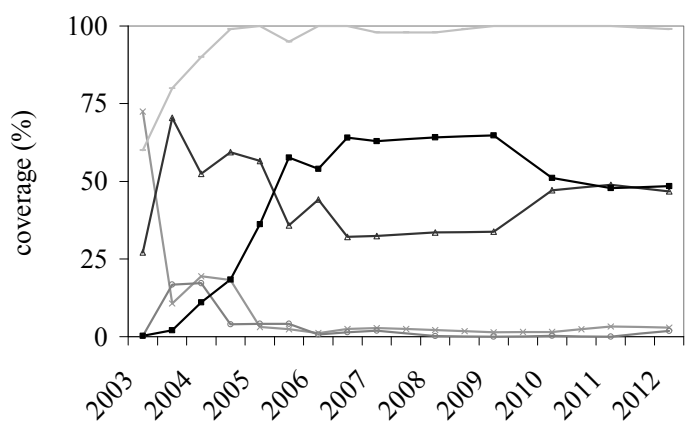

(c)

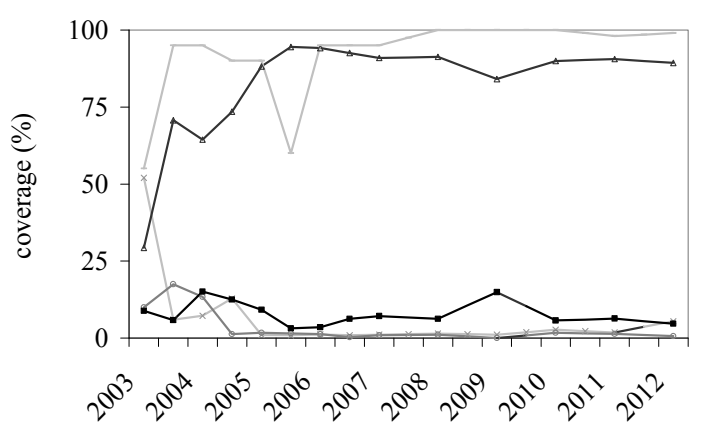

(e)

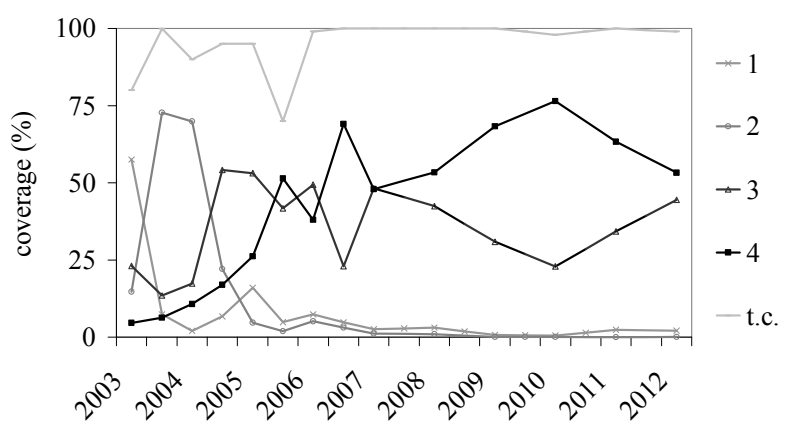

(b)

Site B

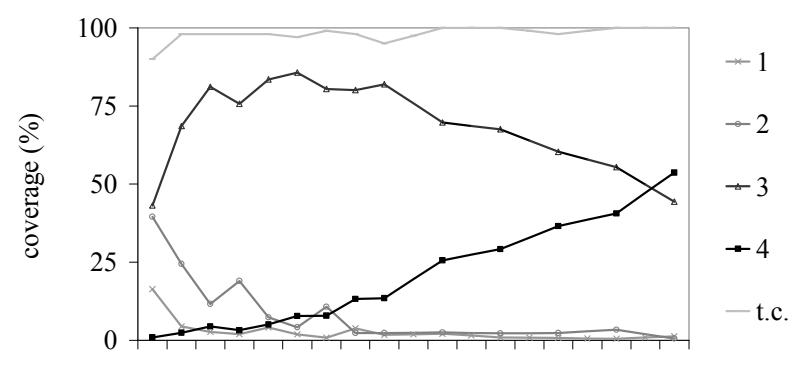

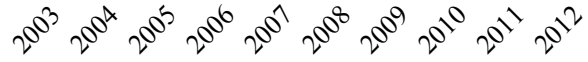

(d)

Site D

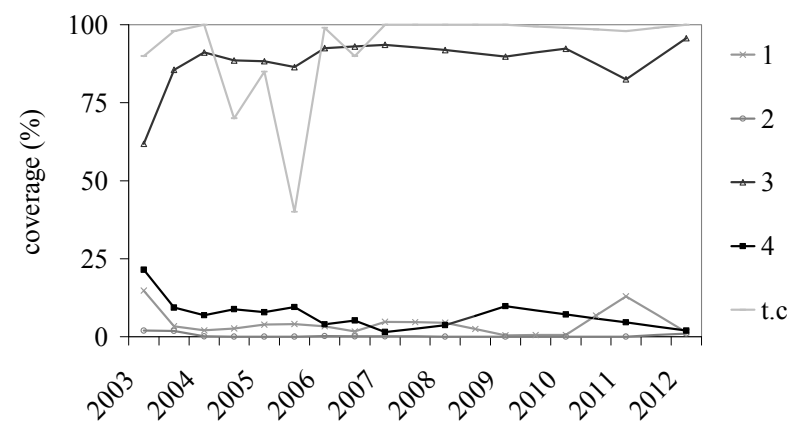

(f)

number of species

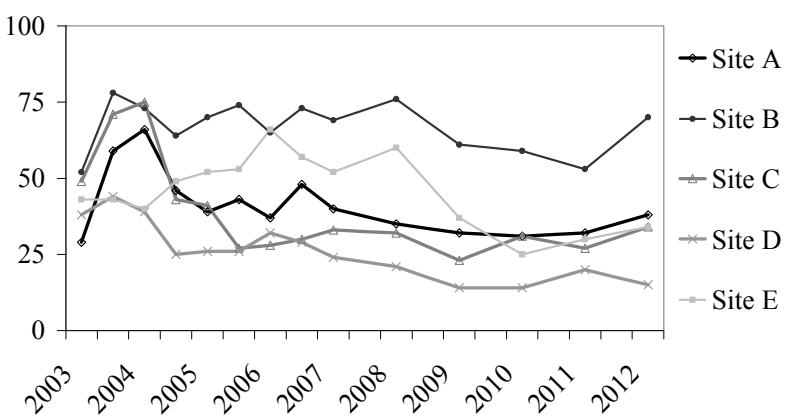

Fig. (1a-e). Development of the portions of ground cover by different life traits for each relevé in percentage of the total vegetation coverage: 1 - annual, 2 - biennial species, 3 - perennial grasses and forbs, 4 - woody species; t. c. - total vegetation coverage in percentage of the total relevé area; (f): total species number of each relevé over the years.

species were still present and biennial species (Verbascum phlomoides and Erigeron canadensis) performed best compared to the other years. First sprouts of Alnus glutinosa appeared. In the third year, Phalaris arundinacea and Alnus glutinosa increased their coverage. Only in summer an amount of non-invasive annual species were added (Vicia hirsuta, Oxalis stricta). In the following years, under the competition of the shrub-shaped Alnus glutinosa, the coverage of Phalaris decreased permanently. However, it remained the dominant species among perennials, even when more and more shade-tolerant species grew up (e.g. Poa trivialis, Lamium maculatum). During the last years these species increased their coverage significantly together with nitrophilous species of floodplain forests (e. g. Urtica dioica, Carduus crispus).

Site B mainly is made up by sandy substrate. In the first year Erigeron canadensis dominated the site. Also Artemisia vulgaris and some perennial grasses (Elymus repens and Poa trivialis) were frequent. Annual species were also present (Persicaria dubia, Apera spica-venti). In the following years Artemisia decreased more and more. For some years, a few Trifolium species became frequent. The annual Apera spicaventi as well reached high cover values for some time. For the whole period under observation medium size grasses were frequent (Poa trivialis, Poa palustris, Agrostis stolonifera). After three years, perennials with a higher moisture demand established themselves (Phalaris arundinacea, Juncus effusus). However, only after four years a clear tendency was observed towards site specific Salix fragilis, Alnus glutinosa, additionally Betula pendula, Carpinus betulus, Pinus sylvestris and Tilia cordata that immigrated from the surrounding forested slopes. The moisture (F)-value increased continuously from 5.6 in 2003 to 7.6 in 2012. 
Site $\mathrm{C}$ is situated directly at the river bank. The substrate is coarse gravel. The vegetation had been completely eradicated by the flood. In the first year mainly annual species emerged (Persicaria sp.). However, the total coverage of the area was comparably low (55\%). From the second year onward Phalaris arundinacea had performed best among all species. Obviously its rhizomes had survived the flood of 2002 in the substrate. Various other species typical for wetlands (Poa trivialis, Stellaria aquatica, Solanum dulcamara) became frequent but not dominant. The last year potentially invasive species established more and more (Urtica dioica, Mentha longifolia). In 2012 tree species did not cover much, even when some individuals grew up to more than two meters (Alnus glutinosa, Salix fragilis). In the spring of 2006 a small flood superposed the substrate with a new layer of gravel and sand. The vegetation was partly buried, and the total coverage was low $(60 \%)$. However, the plants survived, and therefore the succession continued despite the disturbance.

At site $\mathrm{D}$ the vegetation was not totally eradicated in 2002. This can be explained by the mentioned stone hillock and some trees, which protected the site. However, in the first year the coverage by annual species was only about $15 \%$. In the beginning two Veronica species covered about $25 \%$ together, but from the third year on they were absent. The coverage of Juncus effusus was also quite frequent in the second year, but declined to less than $1 \%$. An interesting fact is the decrease of Salix fragilis and all other woody species. Their coverage amounted to more than $20 \%$ in the first year. From the second to the fourth year the coverage remained at a level between 7 and $10 \%$ and declined over the years. In 2007 all woody species together covered less than $2 \%$. The species which has dominated the site since 2004 is Phalaris arundinacea. Even the small flood in the spring of 2006) did not change the situation as it was the case at site $\mathrm{C}$ and $\mathrm{E}$. On the contrary, the coverage of Phalaris increased even from about $60 \%$ in 2005 to about $80 \%$ in summer 2006. A remarkable detail is the presence of Scirpus radicans in the relevé. The species is rare throughout Austria.

Site E started with a typical annual stage (Setaria pumila, Oxalis stricta, Bidens tripartita, and others). In the second year biennial species dominated (mainly Erigeron annuus and Erigeron canadensis). The third year the vegetation became more and more heterogeneous. Trifolium species but also perennial grasses like Poa palustris became more frequent, but did not came to dominance. At the same time tree species grew up. The second flood affected the herbal layer of site $\mathrm{E}$ as well. As a consequence, the total cover of the site decreased. Two months later, however, a great number of new species was identified, mainly perennial grasses and forbs (Fig. (1). After five years the aspect of this site had changed very much. In large parts the trees reached a height of more than four meters. Between these trees meadow species, invasive ruderal species (Cirsium arvense, Mentha longifolia, Calamagrostis epigejos, Phalaris arundinacea, and others) and less-invasive ruderals intermingled. Until 2012 mainly shade-tolerant wetland species performed well (Urtica dioica, Poa palustris, Stellaria aquatica). The site developed similarily to site A (Fig. (3). A remarkable result is the performance of Robinia pseudacacia. This tree is well known in the Kamp valley as an invasive neophyte. It is a typical pioneer on dry sites in the Pannonian area (Protopopova et al. 2006). In the Pannonian climate of the Kamp River Robinia pseudacacia had become such a problem that the county government had started projects to repel this species. Therefore the performance of Robinia is of special interest. In the first year after the flood Robinia pseudacacia covered about $1 \%$, like Alnus glutinosa, Populus nigra and Salix fragilis. As the site is situated about $0.5 \mathrm{~m}$ above the water table, Robinia pseudacacia could cope with the competition of floodplain pioneers until the third year. Then the three other species grew more efficiently, not only in height but also in coverage. Until 2012 especially the coverage of Populus nigra collapsed from about $50 \%$ to less than $1 \%$, whereas the coverage of Robinia increased continuously up to $30 \%$. The second species with a continuous increase of its coverage up to about $10 \%$ is Populus alba.

The new arm below site $\mathrm{E}$ was investigated only in September 2003 and in August 2007. In 2003 short living ruderals and sprouts of black poplar were present. In 2007 the vegetation had a different character. Only few annual species $(4.8 \%)$ and sprouts of trees $(0.2 \%)$ were found. Yet the perennial grasses Phalaris arundinacea and Agrostis stolonifera conquered the area together with Artemisia vulgaris. The succession had not started from an early point, but the surrounding perennial vegetation penetrated into the gaps. Especially the two grasses succeeded in immigrating with their rhizomes and stolones over a distance of only a few meters. From 2008 to 2012 the site was filled with water all the time.

\section{Results of Life Traits, Indicator Values and Diversity}

Fig. (1) displays some effects typical for early successional stages. Annual species in the first year are followed by biennial species in the second year and perennials later. After some years, woody species come to dominance. Site A and site E demonstrate this best. At site B perennial species dominate even in the second year, whereas the coverage of shrubs and trees is still increasing. At site $\mathrm{C}$ and especially site D the perennial Phalaris arundinacea dominated the vegetation from the second year. Woody species seem to be suppressed there by the high water table.

Fig. (1) also shows the changes of total species numbers. Successions often lead to a maximum of short-lived species in the second year ( ites A, C and D). On the one hand the annual species are still present and the biennial species reach their maximum in growth and diversity, on the other hand perennials and especially woody species have already started to establish themselves. Later on, annual and biennial species decrease in number and vitality. Site B shows a small scale vegetation pattern. No species gained dominance until 2012. Due to local disturbances by animals, even annual and biennial species have survived on a low coverage level. Site E became more heterogeneous by the increase of tree species. After the first two years, the trees grew up in some parts of the relevé area. In the sunlit gaps in between, various micro-habitats have established. However, since 2008 the number of species has been reduced drastically.

At some sites the average Ellenberg moisture value shows a marked increase (Fig. (2) as typical wetland species (Alnus glutinosa, Phalaris arundinacea) increased their 
F-value

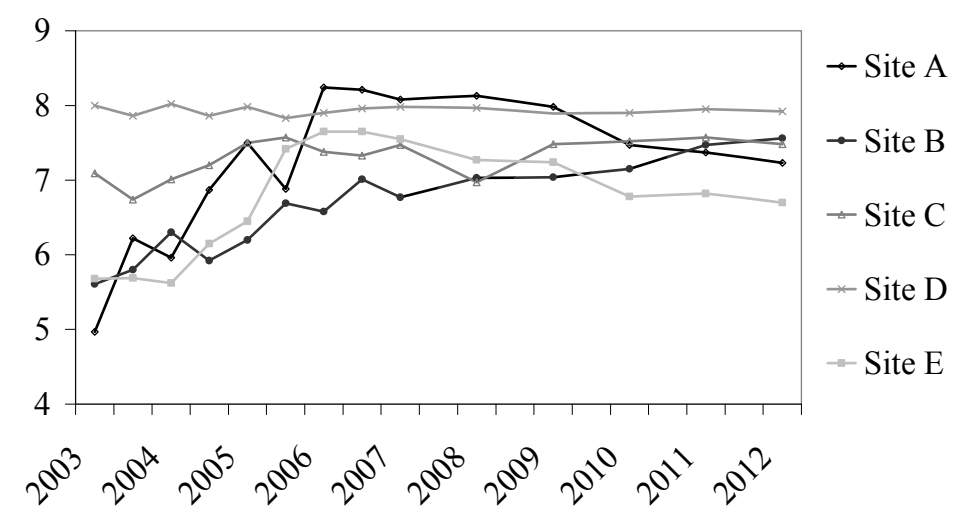

Fig. (2). F- (moisture) indicator value in the course of the years.

(a)

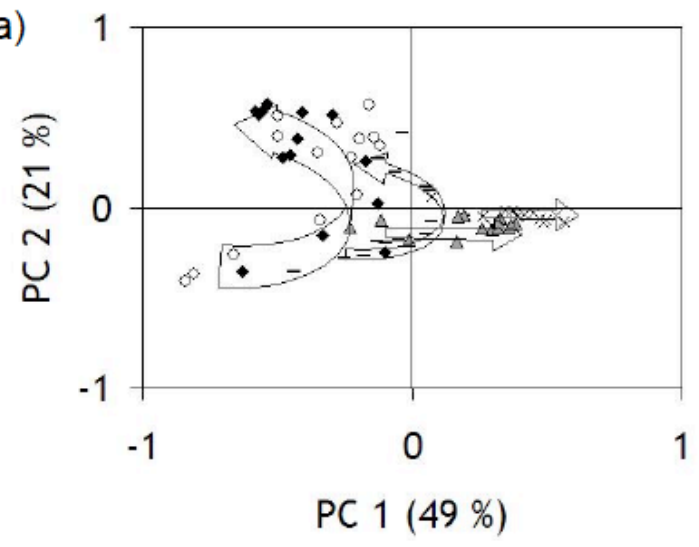

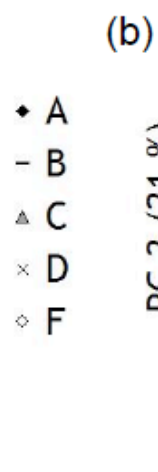

(b)

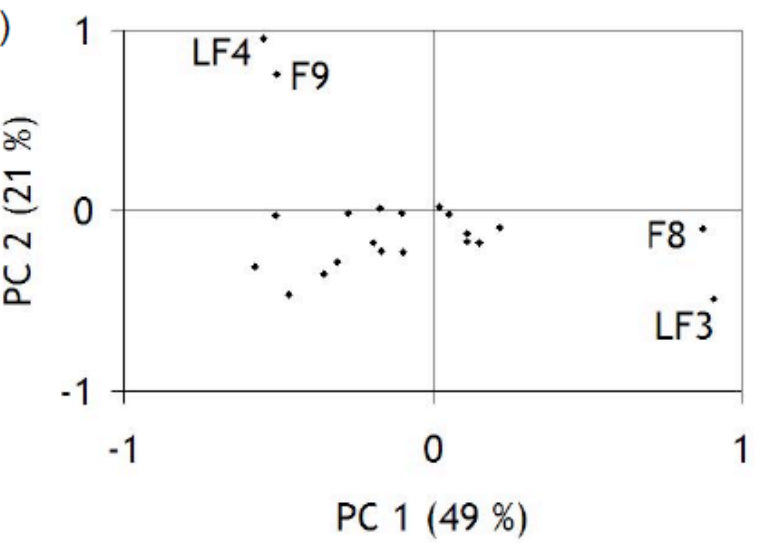

Fig. (3a). scores plot, the arrows indicating the development over the years (explanation of PCs: PC 1: $49 \%$, PC 2: $21 \%$ ); (b) loadings plot. F means moisture indicator value, LF means life trait.

coverage. The annual and biennial species are less moisture demanding. Therefore the F-value started at quite low levels in the first year. Probably even the substrate increased its portion of fine blown-in particles and additionally by the deposit of organic matter. Sites C and D had never lost their connection to the water table; therefore their F-values remained more or less stable.

The indicator values for nutrients and soil reaction did not change significantly.

Castillo-Campos et al. (2008) found out, that in tropical forests in Veracruz, Mexico, species richness was higher in secondary vegetation than in primary forests. Shrubs and herbs contributed more to the vegetation of the former. Similar results are reported by Kreyling et al. (2008) from a long-term succession in British Columbia, Canada.

The following results of PCA illustrate to which successional stages the sites develop (Fig. (3). The first two principal components (PC) of the parameter set described in the Sites and Method chapter of all relevés are shown in figure 3. The loadings plot explains how the parameter set is combined in the PC. Input parameters are the ecological indicator values and the life trait-values. Site A and E tend towards alder/ willow forests whereas sites $\mathrm{C}$ and $\mathrm{D}$ tend more towards a vegetation dominated by Phalaris arundinacea. All sites except D started at an early succession stage (Fig. 3a, lower left corner). Site B started quite similar to site $\mathrm{C}$, but in the last years the tendency towards an alder/ willow forest became obvious.

The calculations of diversity support the observations described above. Evenness was quite high in all relevés of 2003 (Fig. (4). This is remarkable especially for site D. At all sites with a development towards the dominance of one wetland species, evenness decreased. At sites $\mathrm{B}$ and $\mathrm{E}$ the succession did not yet reach such a stage, therefore also evenness is still quite high. During the biennial stage in site E, where Erigeron spp. dominated, evenness was comparatively low.

In Fig. (5) the Sørensen indices of the relevés are displayed with respect to the latest relevé date (2012). Changes in species composition were substantial between 2006 and 2007 and between 2010 and 2012 compared to the other years. Nevertheless, the strongest changes were recorded between the first and the second year. This corresponds to the maximum of species number in these years. It can be concluded that the development over these five years was remarkable. Site A and site E show the most constant increase of the index. In total the sites A, B and E showed the greatest changes as they started from a very early stage of succession. Site D showed the smallest changes, probably due to the small flood of 2006. 


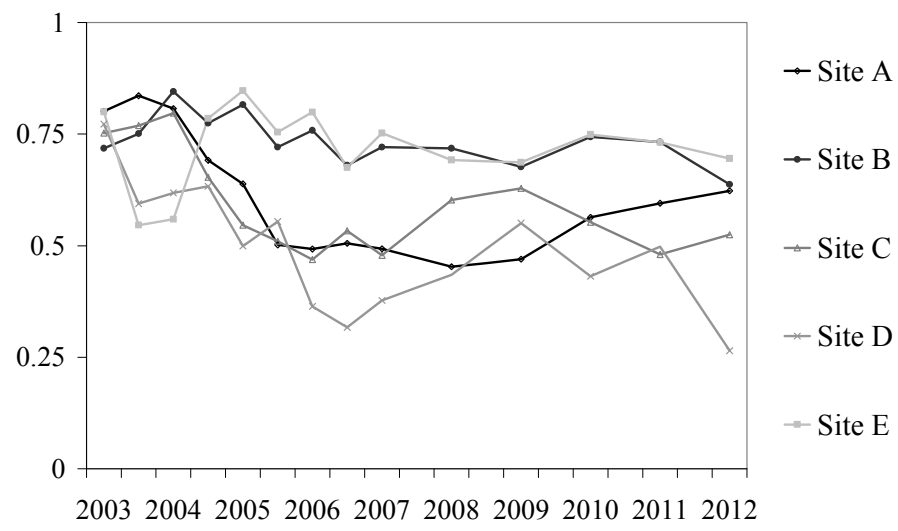

Fig. (4). The development of evenness in all relevés.

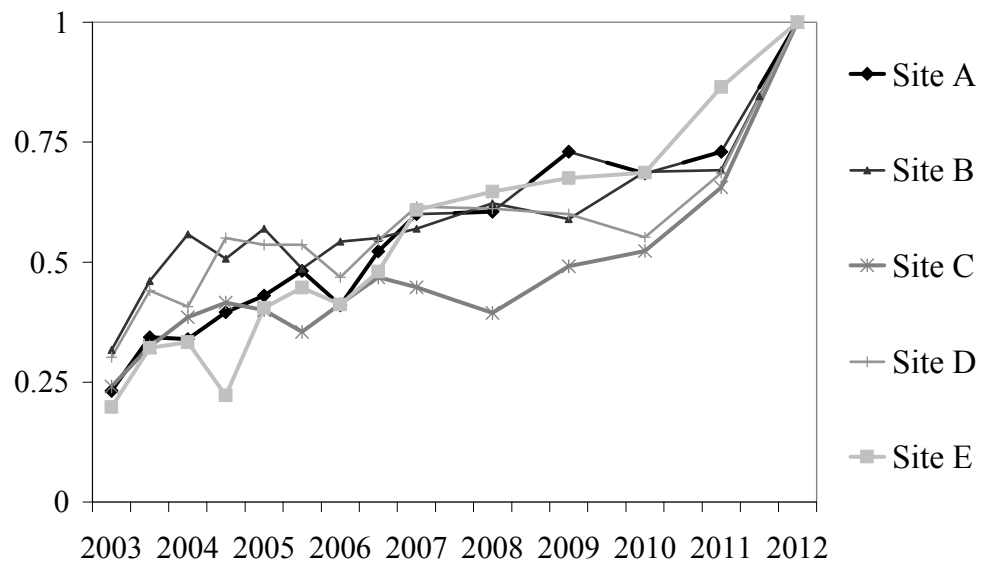

Fig. (5). Sørensen-indices relative to relevés of 2012.

Table 2. Sørensen-Indices Related to Relevés of 2012 and all Relevés of the Years 2003, 2007 and 2012 (First Letter: Site, Number: Year)

\begin{tabular}{|c|c|c|c|c|c|c|c|c|c|c|c|c|c|c|c|}
\hline & A2003 & B2003 & $\mathrm{C2003}$ & D2003 & E2003 & A2007 & B2007 & $\mathrm{C} 2007$ & D2007 & E2007 & A2012 & B2012 & $\mathrm{C} 2012$ & D2012 & F2012 \\
\hline A2012 & 0.23 & 0.22 & 0.22 & 0.15 & 0.30 & 0.60 & 0.27 & 0.30 & 0.22 & 0.38 & 1.00 & & & & \\
\hline B2012 & 0.16 & 0.32 & 0.31 & 0.25 & 0.22 & 0.47 & 0.57 & 0.30 & 0.31 & 0.52 & 0.42 & 1.00 & & & \\
\hline $\mathrm{C} 2012$ & 0.13 & 0.21 & 0.24 & 0.17 & 0.21 & 0.43 & 0.27 & 0.45 & 0.28 & 0.32 & 0.41 & 0.43 & 1.00 & & \\
\hline D2012 & 0.23 & 0.21 & 0.19 & 0.30 & 0.07 & 0.29 & 0.12 & 0.42 & 0.62 & 0.35 & 0.18 & 0.25 & 0.29 & 1.00 & \\
\hline E2012 & 0.21 & 0.18 & 0.14 & 0.18 & 0.20 & 0.46 & 0.28 & 0.23 & 0.35 & 0.61 & 0.51 & 0.45 & 0.31 & 0.38 & 1.00 \\
\hline
\end{tabular}

The relationship of the sites $A$ to $E$ and their development is demonstrated in Table 2. In the last year sites $A$ and $E$ matched best. Interestingly the sites $C$ and D (both dominated by Phalaris arundinacea) differ considerably in their species lists.

Early successional stages as described in this paper seem somehow exotic with regard of maximizing biodiversity, as species numbers or evenness are highest in early stages with a high frequency of annual and biennial ruderal (often neophytic) species. Chabrerie et al. (2001) found the richest plant communities in the Seine estuary between regimes with natural and anthropogenic disturbance.

\section{CONCLUSIONS}

The five sites showed different, but typical early successions after a flood. Some developed from an annual over a biennial towards a perennial stage dominated by trees (in this case Alnus glutinosa or Salix fragilis) or herbaceous plants - mainly grasses (Phalaris arundinacea). Where none of these species comes to early dominance, the succession is decelerated.

The development of the sites could be documented by various parameters. Average ecological moisture values increased at the sites A, B, C and E. This can be explained 
by the increase of the typical vegetation of river sides and wet plains. As the plants grow and root into deeper zones, they reach the water table. This is a clear difference between the adapted species and the ruderals of early stages of succession. Therefore the degree of ruderalization can be displayed by the F-indicator value. PCA was a good tool to get more information about the weighted ecological indicator values of every single relevé. This information is lost by calculating averages.

Evenness is high immediately after the flood, after other disturbances, and where ruderal species can survive alongside with the typical wetland species. As soon as competitive species like black alder or well-adapted clonal grasses like Phalaris arundinacea increase their coverage, evenness decreases. This must be taken into account, whenever evenness is taken as a measure for successful ecological engineering (Pedersen et al. 2007). Corresponding results are reported by Zhang et al. (2007). The parameter evenness depends to a high degree of plant strategies (Grime 2001). Vegetation with dominant competitive species tends to low evenness, whereas ruderals (and especially stresstolerant species, which are less frequent in early succession stages,) form a type of vegetation with higher evenness. Also $\alpha$-diversity, measured as number of species, is higher in early succession stages - especially the biennial stage - with a high percentage of ruderals.

\section{CONFLICT OF INTEREST}

The authors confirm that this article content has no conflicts of interest.

\section{ACKNOWLEDGEMENTS}

Special thanks to DI (FH) Irene Ahamer for providing the evaluation tool of the averaged indicator values and for her help at the relevés. Thanks also to DI (FH) Michael Böhm for providing the evaluation tool of the Sørensen-index and all people supporting the field work.

\section{REFERENCES}

Bråkenhielm, S \& Liu, Q (1998) Long-term effects of clear-felling on vegetation dynamics and species diversity in a boreal pine forest. Biodiversity and Conservation 7, 207-20.

Braun-Blanquet, J (1964) Pflanzensoziologie - Grundzüge der Vegetationskunde, Springer, Vienna.

Castillo-Campos, G, Halffter, G \& Moreno, CE (2008) Primary and secondary vegetation patches as contributors to floristic diversity in a tropical deciduous forest landscape. Biodiversity and Conservation 17, 1701-14.

Chabrerie, O, Poudevigne, I, Bureau, F, Vinceslas-Akpa, M, Nebbache, S, Aubert, M, Bourcier, A \& Alard, D (2001) Biodiversity and ecosystem functions in wetlands: A case study in the estuary of the Seine River, France. Estuaries 24, 1088-96.

Critchley, CNR (2000) Ecological assessment of plant communities by reference to species traits and habitat preferences. Biodiversity and Conservation 9, 87-105.

Ellenberg, H (1996) Vegetation Mitteleuropas mit den Alpen in ökologischer, dynamischer und historischer Sicht. $5^{\text {th }}$ ed., Ulmer, Stuttgart.

Ellenberg, H, Weber, HE, Düll, R, Wirth, V, Werner, W \& Paulißen, D (1992) Zeigerwerte von Pflanzen in Mitteleuropa. $2^{\text {nd }}$ ed. Goeltze, Göttingen.

Fischer, MA, Oswald, K \& Adler, W (2008) Exkursionsflora für Österreich, Liechtenstein und Südtirol. $3^{\text {rd }}$ ed. Biologiezentrum der Oberösterreichischen Landesmuseen.

Grime, JP (2001) Plant strategies, vegetation processes, and ecosystem properties. $2^{\text {nd }} \mathrm{ed}$. Wiley, Chichester.

Karrer, G \& Kilian, W (1990) Standorte und Waldgesellschaften im Leithagebirge Revier Sommerein. Mitteilung Forstlicher Bundesversuchsanstalt Wien 165, 1-244.

Kreyling, J, Schmiedinger, A, Macdonald, E \& Beierkuhnlein, C (2008) Slow understory redevelopment after clearcutting in high mountain forests. Biodiversity and Conservation 17, 2339-55.

Londo, G (1976) The decimal scale for relevés of permanent quadrats. Vegetatio 33, 61-4.

Muhar, S, Poppe, M, Egger, G, Schmutz, S \& Melcher, A (2004) Flusslandschaften Österreichs Bundesministerium für Bildung, Wissenschaft und Kultur, Vienna.

Pedersen, ML, Friberg, N, Skriver, J, Baattrup-Pedersen, A \& Larsen, SE (2007) Restoration of Skjern River and its valley-Short-term effects on river habitats, macrophytes and macroinvertebrates. Ecological Engineering 30, 145-56.

Protopopova, VV, Shevera, MV \& Mosyakin, SL (2006) Deliberate and unintentional introduction of invasive weeds: A case study of the alien flora of Ukraine. Euphytica 148, 17-33.

Smidt, E, Tintner, J \& Meissl, K (2007) New Approaches of Landfill Assessment and Monitoring, In: Velinni, AA (Ed.), Landfill Research Trends, NOVA Publishing NY., pp. 191-225.

Sørensen, T (1948) A method of establishing groups of equal amplitude in plant sociology based on similarity of species and its application to analyses of the vegetation on Danish commons. Biologiske Skrifter/ Kongelige Danske Videnskabernes Selskab 5, 1-34.

Tilman, D (1988) Plant strategies and the dynamics and structure of plant communities Princeton Univ. Pr, Princeton.

Tintner, J \& Klug, B (2006) Standortsbeurteilung auf Deponien mithilfe der Vegetationsökologie, In: Kühle-Weidemeier, M (Ed.), Abfallforschungstage, Cuvillier, Hannover.

Tintner, J \& Klug, B (2011) Can vegetation indicate landfill cover features? Flora: Morphology, Distribution, Functional Ecology of Plants 206, 559-66.

Tremp, H (2005) Aufnahme und Analyse vegetationsökologischer Daten Ulmer, Stuttgart.

Zhang, GS, Wang, RQ \& Song, BM (2007) Plant community succession in modern Yellow River Delta, China. Journal of Zhejiang University. Science. B. 8, 540-8. 